\title{
Evidence for Multiple Mechanisms of Polyclonal T Cell Activation in Murine Lupus
}

\author{
Ram Raj Singh, ${ }^{\star}$ Bevra H. Hahn, ${ }^{\ddagger}$ Betty P. Tsao, ${ }^{\ddagger}$ and Fanny M. Ebling ${ }^{\ddagger}$ \\ *Autoimmunity and Tolerance Laboratory and ${ }^{\ddagger}$ Lupus Research Laboratories, Department of Medicine, UCLA, Los Angeles, \\ California 90095
}

\begin{abstract}
Individuals with systemic autoantibody-mediated diseases such as lupus have polyclonal $\mathrm{T}$ and $\mathrm{B}$ cell activation. Yet, autoantibody production is restricted to certain autoantigens. The mechanisms underlying this phenomenon remain unclear. We propose three potential mechanisms by which autoreactive helper $T$ cell responses diversify to become polyclonal, yet are restricted to certain antigens. First, using a model where self-Ig peptides spontaneously activate $\mathbf{T}$ cells and modulate disease in lupus mice, we demonstrate that the numbers of autoantibody-augmenting $T$ helper peptides increased across the Ig molecule as mice aged ("intramolecular determinant spreading"). Secondly, a single T cell hybridoma established from a $(\mathrm{NZB} \times \mathrm{NZW}) \mathrm{F}_{1}$ mouse immunized with one self-Ig peptide recognized several Igderived determinants, which had little sequence homology with the immunizing peptide. Such determinant degeneracy can lead to polyclonality. To explore a mechanism for restriction to certain autoantigens, a protein database search was done for homologies with sequences of selected stimulatory Ig peptides. Identical sequences of such determinants were not found in murine proteins other than Ig. These occurred infrequently in nonautoantibody Ig, but quite commonly in lupus-related autoantibodies such as antibodies to DNA, cardiolipin, and erythrocytes. Thus, determinant spreading and degenerate recognition in $T$ cells coupled with recurring use of $T$ cell determinant sequences among autoantibodies result in polyclonality that is restricted to certain autoantigens. (J. Clin. Invest. 1998. 102:1841-1849.) Key words: animal model • autoantibodies • autoimmunity • systemic lupus erythematosus $\bullet T$ helper cells
\end{abstract}

\section{Introduction}

Mechanisms by which patients with autoimmune diseases such as SLE develop immune responses to several self-antigens re-

This work was presented in part at the annual meetings of the American College of Rheumatology and the American Federation for Medical Research and has been published in abstract form (1995. Arthritis Rheum. 38:S299) (1997. J. Invest. Med. 45:112A).

Address correspondence to Ram Raj Singh, M.D., Division of Immunology, Department of Medicine, University of Cincinnati College of Medicine, and Veterans Administration Medical Center, Research (151), 3200 Vine St., Cincinnati, OH 45220. Phone: 513-5584701; FAX: 513-487-6611; E-mail: rasingh@med1.medsch.ucla.edu

Received for publication 29 April 1998 and accepted in revised form 11 September 1998.

J. Clin. Invest.

(C) The American Society for Clinical Investigation, Inc. 0021-9738/98/11/1841/09 \$2.00

Volume 102, Number 10, November 1998, 1841-1849

http://www.jci.org main largely unknown. In animal models of SLE, autoantibody (autoAb) ${ }^{1}$ production is associated with polyclonal $\mathrm{T}$ and $\mathrm{B}$ cell activation (1-5). Polyclonal activation actually precedes the development of autoAb and disease $(3,5)$. On the other hand, autoAb production in human and murine SLE also results from antigen-driven responses (for reviews see references 1 and 6). How can we reconcile these two apparently opposing views?

We have shown previously that young lupus-prone $(\mathrm{NZB} \times$ $\mathrm{NZW}) \mathrm{F}_{1}\left[\mathrm{BWF}_{1}\right]$ mice develop spontaneous $\mathrm{T}$ cell activation to several peptides derived from syngeneic autoAb heavy chain variable $\left(\mathrm{V}_{\mathrm{H}}\right)$ regions, but to few if any peptides from a nonautoAb Ig using the same $\mathrm{V}_{\mathrm{H}}$ gene family $(7,8)$. Similar spontaneous $\mathrm{T}$ cell responses are not observed in normal mouse strains (7). Upon immunization with the whole autoAb molecule, recall $\mathrm{T}$ cell proliferative and helper responses to the individual determinants develop in young $\mathrm{BWF}_{1}$ and $\mathrm{MHC}$ class II-matched animals $(9,10)$, providing evidence for in vivo processing of Ig molecules into these ligands in autoimmune and normal strains. Several lines of evidence suggest that these peptides are important in the production of $\mathrm{Ab}$ to doublestranded DNA (dsDNA) and pathogenesis. First, these peptides increase in vitro production of IgG anti-DNA when cultured with $\mathrm{T}$ and $\mathrm{B}$ cells from unimmunized $\mathrm{BWF}_{1}$ mice (shown in this paper). Second, immunization with these peptides accelerates autoAb production and lupus nephritis in $\mathrm{BWF}_{1}$ mice $(8,10)$. Adoptive transfer of peptide-specific $\mathrm{T}$ cells in young $\mathrm{BWF}_{1}$ mice accelerates disease (10). Third, immune tolerance induction to these peptides in prenephritic $\mathrm{BWF}_{1}$ mice decreases anti-dsDNA levels, delays onset of nephritis, and prolongs survival (7). Since tolerization to just three peptides from a single $\mathrm{V}_{\mathrm{H}}$ molecule conferred significant influence on disease, such treatment should have targeted a broad repertoire of autoreactive $\mathrm{T}$ helper cells.

Similar findings have been reported recently in another model of SLE, where two $\mathrm{V}_{\mathrm{H}}$ peptides derived from an antiDNA mAb modulated in vivo anti-DNA production and disease (11). T cells from people with SLE are also activated by Ig $\mathrm{V}_{\mathrm{H}}$ peptides $(12,13)$. Evidence for the role of Ig peptide-reactive $\mathrm{T}$ cells in other autoimmune diseases is accumulating (14, 15). For example, in RA patients, self-Ig heavy chain polypeptides activate autoreactive $\mathrm{CD} 4^{+} \mathrm{T}$ cells derived from arthritic joints (15). The mechanisms by which these self-Ig peptidereactive $\mathrm{T}$ cells arise and influence autoimmune disease are not clear.

Here, using our model of self-antigenic stimulation by autoAb-derived peptides, we tested three potential mechanisms by which autoreactive $\mathrm{T}$ helper responses may diversify in lupus. First, a sequential diversification of $\mathrm{T}$ helper determinants

1. Abbreviations used in this paper: $\mathrm{AFC}, \mathrm{Ab}$-forming cell; $\mathrm{APC}$, antigen-presenting cell; autoAb, autoantibody; $\mathrm{BWF}_{1},(\mathrm{NZB} \times \mathrm{NZW}) \mathrm{F}_{1}$; ds, double-stranded; HEL, hen egg lysozyme; snRNP, small nuclear ribonucleoprotein; ss, single-stranded; TCR, $\mathrm{T}$ cell receptor; $\mathrm{V}_{\mathrm{H}}$, variable region of heavy chains. 
from a self-Ig molecule occurs; $\mathrm{T}$ cell responses spread from 2 of 23 overlapping $\mathrm{V}_{\mathrm{H}}$ peptides in 5-wk-old $\mathrm{BWF}_{1}$ mice to 11 of 23 in 20-wk-old mice. Second, T cell hybridomas established from a mouse immunized with one self-peptide recognized several self-Ig peptides, suggesting a degeneracy in autoimmune $\mathrm{T}$ cell recognition. Thirdly, sequences similar to selfIg-derived $\mathrm{T}$ cell determinants frequently recur in anti-DNA and other lupus-related autoAb, but not in nonautoAb Ig.

\section{Methods}

Mice. $\mathrm{BWF}_{1}, \mathrm{BALB} / \mathrm{c}$, and $(\mathrm{BALB} / \mathrm{c} \times \mathrm{NZW}) \mathrm{F}_{1}$ mice were bred in the UCLA Rheumatology Vivarium or were obtained from The Jackson Laboratory (Bar Harbor, ME). Only female mice were used in these experiments.

Peptides. 15-mer overlapping peptides representing the entire $\mathrm{V}_{\mathrm{H}} \mathrm{D}$ region sequence of a pathogenic anti-dsDNA mAb (A6.1) (16) and a control mAb to hen egg lysozyme (HEL), HYHEL-5 (17), were synthesized using a pin synthesis method (8). Both mAbs use the $\mathrm{V}_{\mathrm{H}} \mathrm{J} 558$ gene family $(16,17)$. Each 15 -mer peptide overlapped its neighbor by 10 residues. Previously characterized 12 -mer determinants, nonstimulatory Ig peptide controls, and a non-Ig foreign peptide, HEL 106-116 (HEL p106), were synthesized by FMOC chemistry at the UCLA Peptide Synthesis Facility or Chiron Technologies (Clayton, Australia) (10). Peptides were analyzed for purity by HPLC and by mass spectrometry. Characteristics of peptides are shown in Table I.

Purification of $T$ and $B$ cells. Single splenic cell suspensions, purified as mononuclear cells on Ficoll-Hypaque, were enriched for T and B cells with the Vario MACS ${ }^{\circledR}$ magnetic purification system using appropriate microbead-coated Ab (Miltenyi, Auburn, CA). Purity of the isolated cell populations as determined by FACS ${ }^{\circledR}$ varied from 92 to $99 \%$.

Determination of $T$ cell help for anti-DNA synthesis in ELISPOT assays. Sonicated calf thymus dsDNA (Sigma Chemical Co., St. Louis, MO) was filtered to remove single-stranded DNA (ssDNA), coated onto 96-well microtiter plates (Costar Corp., Cambridge, MA), and incubated overnight at $4^{\circ} \mathrm{C}$ (17a). After washing with PBS, dsDNA-coated plates were blocked for $1 \mathrm{~h}$ with $10 \%$ FCS in PBS at room temperature. Splenic cells in complete medium (DMEM with $10 \% \mathrm{FCS}), 10^{5} \mathrm{~B}$ cells, and $10^{6} \mathrm{~T}$ cells, with varying concentrations of peptides, were added to each well. After $8-10 \mathrm{~h}$ of incubation at $37^{\circ} \mathrm{C}$, cells were poured off and plates were washed eight times. Plates were then incubated overnight at $4^{\circ} \mathrm{C}$ with alkaline phosphatase-conju- gated anti-mouse IgG, diluted 1:500 in 10\% FCS in PBS. Plates were washed again with Tris-Tween and incubated with a mixture of BCIP ( 5 bromo- 4 chloro 3 indolyl phosphate) and agarose gel in a final concentration of $0.6 \%$. Anti-dsDNA Ab-forming cells (AFCs) were enumerated as blue spots using an inverted microscope (Leitz) and recorded as number of AFCs per $10^{5} \mathrm{~B}$ cells.

The specificity of anti-dsDNA ELISPOT was confirmed by competitive inhibition studies; the anti-dsDNA ELISPOT was inhibited by DNA in a dose-dependent manner. In contrast, there was no inhibition with cardiolipin (data not shown) or with HEL (17a, 17b). The anti-dsDNA ELISPOT was inhibited by both dsDNA and ssDNA but it required two times more ssDNA than dsDNA for 50\% inhibition. Similarly, for anti-ssDNA ELISPOT, 50\% inhibition required five times more dsDNA than ssDNA (17a and data not shown). These data are consistent with previous observations that some populations of anti-DNA include Abs that share dsDNA and ssDNA binding specificities.

The results of ELISPOT assays for anti-dsDNA were further confirmed in simultaneous ELISA experiments, where $\mathrm{T}$ and $\mathrm{B}$ cells were cultured with peptides for $5 \mathrm{~d}$, after which supernatants were tested for IgG anti-dsDNA. The results of ELISA and ELISPOT assays were quite similar (data not shown).

Establishment of p58-specific T cell hybridomas. Lymph node or spleen cells from peptide-immunized $\mathrm{BWF}_{1}$ mice were fused with the $\alpha^{-} \beta^{-}$variant of BW5147. Peptide-specific hybridoma lines were selected, and subcloned two to five times by limiting dilution. To subclone, single cell suspensions of hybridoma lines were prepared in $0.2 \%$ bacto-agar in DMEM with $10 \%$ FBS at $37^{\circ} \mathrm{C}$. This mixture was serially transferred to a set of 8-12 culture tubes until a concentration of 1-10 cells per tube was achieved. These tubes were then allowed to solidify on ice for $10 \mathrm{~min}$. Then $2 \mathrm{ml}$ of medium was added, and tubes were cultured in $\mathrm{CO}_{2}$ incubator. The medium was changed every $48 \mathrm{~h}$. After 10-15 d, individual colonies were picked, expanded in complete $\mathrm{T}$ cell medium, and were further subcloned for another one to five times.

Determining antigen reactivity of hybridomas. $\mathrm{T}$ cell hybridomas were tested for antigen specificity after several (four to six) cycles of periodic stimulation and rest. $5 \times 10^{4}$ resting hybridoma cells were incubated in $200-\mu l$ volumes in microtiter wells containing $5 \times 10^{5}$ irradiated splenic cells as antigen-presenting cells (APCs) and various concentrations of relevant or control peptides. Supernatants were harvested at $24 \mathrm{~h}$ and incubated with HT-2 cells for $24 \mathrm{~h}$ at $37^{\circ} \mathrm{C}$ in $5 \% \mathrm{CO}_{2} .1 \mu \mathrm{Ci}$ of $\left[{ }^{3} \mathrm{H}\right]$ thymidine was added to each well. $16-18 \mathrm{~h}$ later the cells were harvested (Skatron), and $\beta$ emissions were counted as cpm. Proliferation of HT-2 cells is shown as a measure of IL-2 produced by activated hybridoma cells.

Table I. Characteristics of Peptides Used in the Study

\begin{tabular}{|c|c|c|c|c|}
\hline Peptides* & Molecule (ref. 16) & Location & Sequence (refs. 7, 8, and 10) & MHC II restriction (ref. 10) \\
\hline p11 & A6.1 $\mathrm{V}_{\mathrm{H}}$ & 11-22, FR1 & LVKPGASVKMSC & ND \\
\hline p31 & A6.1 $\mathrm{V}_{\mathrm{H}}$ & 31-38, CDR1/FR2 & GYFMNWVK & ND \\
\hline p34 & A6.1 $\mathrm{V}_{\mathrm{H}}$ & 34-45, CDR1/FR2 & MNWVKQSHGKSL & $I-E^{d}$ \\
\hline p58 & A6.1 $\mathrm{V}_{\mathrm{H}}$ & 58-69, CDR2/FR3 & FYNQKFKGKATL & $\mathrm{I}-\mathrm{E}^{\mathrm{d}}$ and $\mathrm{I}-\mathrm{E}^{\mathrm{u}}$ \\
\hline p84 & A6.1 $\mathrm{V}_{\mathrm{H}}$ & 84-95, FR3/CDR3 & SEDSALYYCARD & $\mathrm{I}-\mathrm{A}^{\mathrm{u}}$ \\
\hline p93 & A6.1 $\mathrm{V}_{\mathrm{H}}$ & 93-107, FR3/CDR3 & ARDSPYYYGSSYGFA & $\mathrm{I}-\mathrm{A}^{\mathrm{u}}$ \\
\hline p33 & BWds3 $V_{H}$ & 33-47, CDR1/FR2 & FITWVKQRTGQGLEW & ND \\
\hline HEL p106 & HEL & $106-116$ & NAWVAWRNRCK & $\mathrm{I}-\mathrm{E}^{\mathrm{d}}$ \\
\hline
\end{tabular}

* Peptides p11, p34, p58, p84, and p33 are stimulatory Ig peptides that induce spontaneous $\mathrm{T}$ cell help for anti-DNA Ab in unimmunized BWF mice (Refs. 7, 8, and 10, and Table II). Peptides p31 and p93 are from the A6.1 $\mathrm{V}_{\mathrm{H}}$; they do not induce spontaneous proliferation of BWF $\mathrm{T}_{1}$ cells, but can elicit immune response when injected in vivo with adjuvant (data not shown). HEL p106 is an immunodominant peptide in H-2 ${ }^{\mathrm{d}}$ mice. HEL p106 binds I- $\mathrm{E}^{\mathrm{d}}$, as do $\mathrm{p} 34$ and $\mathrm{p} 58$ (10). HEL p106 does not spontaneously activate $\mathrm{BWF}_{1} \mathrm{~T}$ cells, but elicits strong $\mathrm{T}$ cell proliferation in $\mathrm{BWF}_{1} \mathrm{mice}$ upon immunization (10). ${ }^{\ddagger} \mathrm{A} 6.1$ and Bwds3 are IgG2a anti-dsDNA mAbs derived from nephritic BWF $\mathrm{F}_{1}$ mice (16). Both bind dsDNA with high avidity, fix complement well, and cause nephritis when transferred to BALB/c mice. Both mAbs use J558 $\mathrm{V}_{\mathrm{H}}$ gene family (16). $N D$, not determined. 
Database search for identical sequences. Several Ig peptides were used in BLAST searches screened for identical matches and for changes from germline in the all nonredundant GenBank database containing nucleotide sequences translated into reading frames.

\section{Results}

Ig-derived $T$ cell determinants increase in vitro IgG anti-dsDNA Ab production

To further understand the basis of in vivo upregulation of autoimmunity by autoAb-derived peptides (7-10), we investigated their ability to modulate anti-DNA production in vitro. Splenic $\mathrm{T}$ and $\mathrm{B}$ cells from 20 -wk-old unimmunized $\mathrm{BWF}_{1}$ mice were cultured with A6.1 $\mathrm{V}_{\mathrm{H}}$ determinants (p11, p34, p58, and p84), control peptides from the same molecule (p31 or p93), and a foreign peptide (HEL p106) in 96-well plates coated with dsDNA or HEL. IgG anti-dsDNA and anti-HEL $\mathrm{Ab}$ production was determined as AFCs in ELISPOT assays. A6.1 determinants significantly increased the number of antidsDNA AFCs compared with the background ( $\mathrm{T}$ and $\mathrm{B}$ cells alone, no peptide) or peptide controls (p31, p93, or HEL p106) (Table II). No anti-HEL AFCs were detected in these mice. The increase in anti-DNA Ab by A6.1 determinants was T cell driven, since peptides cultured with B cells alone had no effect on anti-DNA AFCs (data not shown).

To further test the specificity of ELISPOT assay for antiDNA, parallel experiments were done to enumerate a control IgG AFC, anti-HEL. 12-wk-old $\mathrm{BWF}_{1}$ mice were immunized with HEL p106 in CFA and boosted with HEL p106/IFA. At

Table II. Ig-derived T Cell Determinants Increase In Vitro IgG Anti-dsDNA Production

\begin{tabular}{lcc}
\hline \multicolumn{1}{c}{ Peptides } & $\begin{array}{c}\text { IgG anti-dsDNA } \\
\text { AFC }\end{array}$ & $\begin{array}{c}\text { IgG anti-HEL } \\
\text { AFC }\end{array}$ \\
\hline & mean \pm SEM & mean \pm SEM \\
Unimmunized BWF mice & & \\
None (B + T cells alone) & $20 \pm 4$ & 0 \\
HEL p106 (control) & $18 \pm 3$ & 0 \\
p31 (control) & $22 \pm 1$ & ND \\
p93 (control) & $19 \pm 2$ & ND \\
p11 & $81 \pm 4^{*}$ & 0 \\
p34 & $55 \pm 4^{*}$ & 0 \\
p58 & $57 \pm 2^{*}$ & 0 \\
p84 & $43 \pm 1^{*}$ & 0 \\
HEL p106-immunized BWF 1 mice & & \\
None (B + T cells alone) & $36 \pm 4$ & $26 \pm 4$ \\
p106 & $39 \pm 3$ & $141 \pm 12^{\ddagger}$ \\
p11 & $71 \pm 6^{\S}$ & $26 \pm 3$ \\
p58 & $63 \pm 7^{\S}$ & $28 \pm 3$ \\
p84 & $71 \pm 8^{\S}$ & $15 \pm 2$ \\
\end{tabular}

For unimmunized $\mathrm{BWF}_{1}$ mice, results are shown as the mean $\pm \mathrm{SEM}$ AFCs per $10^{5} \mathrm{~B}$ cells from one to five similar experiments. $* P<0.001$ to $<0.05$ (Student's $t$ test) compared with the no peptide (None), HEL p106, and nonstimulatory Ig peptide controls. $N D$, not determined. For HEL p106-immunized $\mathrm{BWF}_{1}$ mice, results are from one of two similar experiments. ${ }^{\ddagger} P<0.001$ (Student's $t$ test) compared with the no peptide (None) or Ig peptide controls. ${ }^{\S} P<0.05$ to $<0.001$ (Student's $t$ test) compared with the no peptide (None) or HEL p106 controls. Six mice were used in each experiment.
20 wk of age, their splenic T and B cells were cultured with HEL p106 or Ig peptides in 96-well plates coated with HEL or dsDNA. The IgG anti-HEL AFCs were increased in the presence of HEL p106, and anti-DNA AFCs were increased in the presence of Ig peptides, compared with background or peptide controls (Table II).

Increasing numbers of peptides from auto $A b V_{H}$ regions provide spontaneous $T$ cell help in $B W F_{1}$ mice as they age

We determined sequential appearance of IgG anti-DNA-augmenting $\mathrm{T}$ helper peptides from the $\mathrm{V}_{\mathrm{H}}$ region of a mAb antiDNA (A6.1). 23 overlapping 15-mer peptides representing the entire A6.1 $V_{H}$ were incubated with splenic $T$ and $B$ cells from unimmunized $\mathrm{BWF}_{1}$ mice of various ages. Several peptides increased the number of IgG anti-dsDNA AFCs two- to eightfold above background (Fig. $1 A$ ). At 5 wk of age, only two peptides from the CDR1/FR2 region of the $V_{H}$ increased the number of anti-DNA AFCs. These two initial determinants, peptides 7 and 9 (Fig. 1 A, left), represent A6.1 $\mathrm{V}_{\mathrm{H}} 31-45$ and 41-55, and share several residues with a previously characterized determinant p34 (A6.1 $\mathrm{V}_{\mathrm{H}}$ 34-45) (10). At later ages, the number of peptides that activated $\mathrm{T}$ cell help steadily increased. The mean numbers of stimulatory peptides were 2,3 , 8 , and 11 at $5,10,15$, and $20 \mathrm{wk}$ of age, respectively. Thus, at an early age in $\mathrm{BWF}_{1}$ mice, the spontaneous $\mathrm{T}$ cell response against anti-DNA $\mathrm{V}_{\mathrm{H}}$ molecules is restricted to a few determinants. With time this response gradually spreads across the molecule. (In $\mathrm{BWF}_{1}$ females in our colonies, IgG anti-dsDNA appear at $\sim 15-20$ wk of age; proteinuria appears at $\sim 22-30$ wk, and mean life span is $38 \mathrm{wk}$.)

To test the specificity of $\mathrm{T}$ cell help for anti-DNA production, 21 overlapping peptides derived from a control anti-HEL mAb, HYHEL-5, that uses the same $V_{H}$ gene family as A6.1 (17), were incubated with splenic T and B cells from 30-wk-old $\mathrm{BWF}_{1}$ mice. Only one peptide activated $\mathrm{T}$ cells that helped anti-DNA production (Fig. $1 B$ ). This suggests that spontaneous $\mathrm{T}$ helper determinant spreading, rampant among auto $\mathrm{Ab}$ derived peptides in older $\mathrm{BWF}_{1}$ mice, is not seen in peptides from a foreign $\mathrm{Ab}$. However, occasional peptides from a foreign $\mathrm{mAb}$ can help autoAb production.

\section{Patterns of recognition of $T$ cell hybridomas from a $B W F_{1}$ mouse immunized with p58}

To explore the possibility of degenerate recognition of determinants by autoreactive $\mathrm{T}$ cells, several $\mathrm{T}$ cell hybridomas were established from a $\mathrm{BWF}_{1}$ mouse immunized with $\mathrm{p} 58$. Nine of these hybridomas were cultured with or without $\mathrm{BWF}_{1}$ APCs and several peptides listed in Table I. Culture supernatants were incubated with HT-2 cells; activation was assayed as proliferation of HT-2 cells. The nine T cell hybridomas could be categorized into three types (Fig. 2).

Hybridomas that are exquisitely peptide specific. Four hybridomas were stimulated only in the presence of p58 and not in the presence of other self- (p34 and p84) or exogenous (HEL p106) peptides. An example of one such hybridoma (T21.8.3) is shown in Fig. 2 (left).

Degenerate hybridomas recognizing several self-Ig peptides but not an exogenous peptide. Two hybridomas were stimulated in the presence of several self-peptides tested, but not in the presence of APCs alone (hybridoma T21.8.13 in Fig. 2, middle). It is intriguing to note that these three peptides bind different MHC class II molecules. The peptide p34 binds I- $\mathrm{E}^{\mathrm{d}}$, 
(A) A6.1 VH Peptides

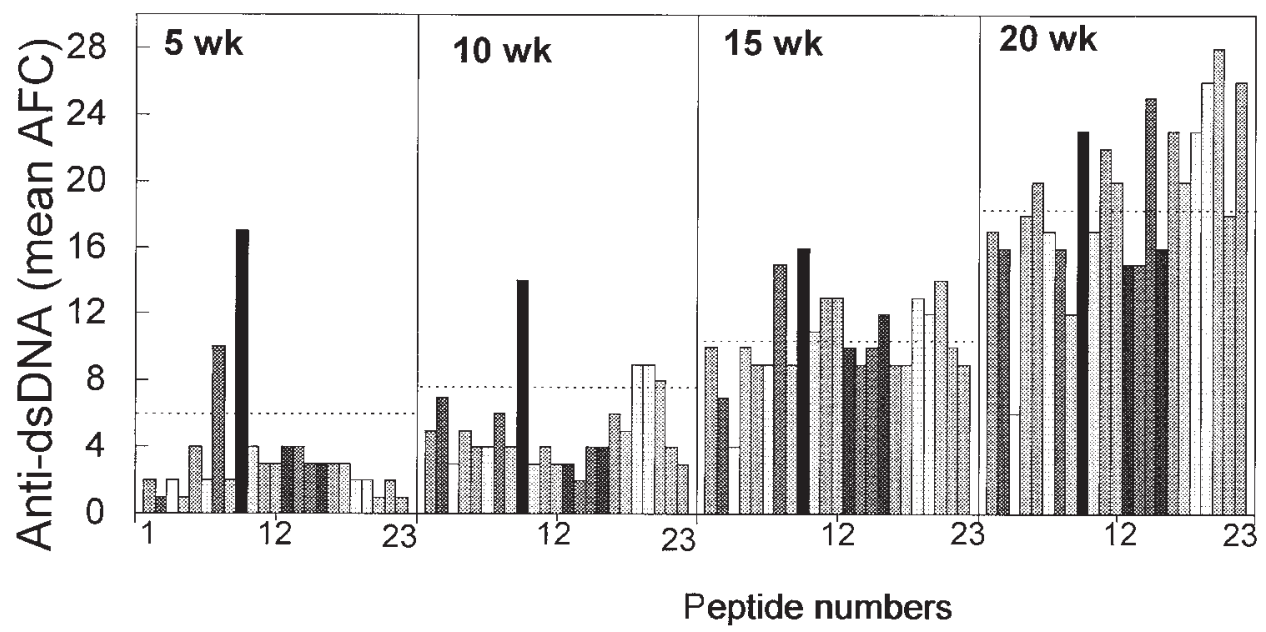

(B) HYHEL-5 VH Peptides

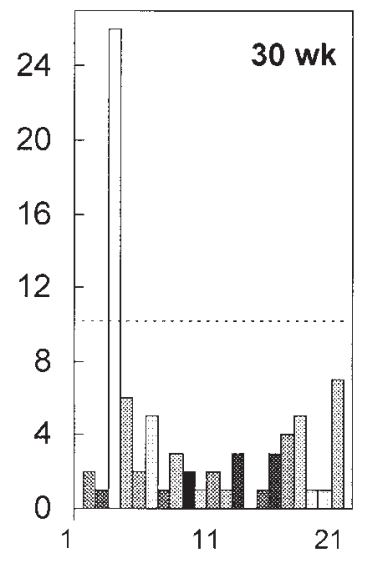

Figure 1. (A) Intramolecular $\mathrm{T}$ helper determinant spreading across an anti-DNA $\mathrm{V}_{\mathrm{H}}$ molecule as $\mathrm{BWF}_{1}$ mice age. Splenic $\mathrm{T}$ and $\mathrm{B}$ cells from $\mathrm{BWF}_{1}$ mice of different age groups $(5,10,15$, and $20 \mathrm{wk})$ were incubated with 23 peptides from the $\mathrm{A} 6.1 \mathrm{~V}_{\mathrm{H}}$ in 96 -well microtiter plates coated with calf thymus DNA. IgG anti-dsDNA AFCs were enumerated in ELISPOT assays. Results are expressed as the mean of mean AFC number per $10^{5} \mathrm{~B}$ cells in three separate experiments. The cutoff denoted by horizontal dashed lines across the figures represents AFC number twofold above background in cultures of $\mathrm{T}$ and $\mathrm{B}$ cells without peptides. The increasing background anti-DNA AFCs with age is a common finding in $\mathrm{BWF}_{1}$ mice and may correspond to the in vivo activation status of $\mathrm{T}$ and $\mathrm{B}$ cells. Note that the number of peptides that stimulated in vitro $\mathrm{T}$ cell help for IgG anti-dsDNA production increased from 2 at $5 \mathrm{wk}$ of age to 11 at $20 \mathrm{wk}$ of age. $(B)$ To test the specificity of T cell help from antiDNA-derived peptides, we cultured splenic $\mathrm{T}$ and $\mathrm{B}$ cells from 30 -wk-old $\mathrm{BWF}_{1}$ mice with 21 overlapping peptides from a control mAb antiHEL (HYHEL-5). Results are shown as the mean IgG anti-dsDNA AFCs per $10^{5}$ B cells. Only one peptide (No. 3) helped anti-DNA production. The sequences of peptide 3 in A6.1 and HYHEL-5 are LVKPGASVKMSCKAS and LMKPGASVKISCKGY, respectively (the residues in HYHEL-5 that are different from those in A6.1 are underlined).

p58 is restricted by both $\mathrm{I}-\mathrm{E}^{\mathrm{d}}$ and $\mathrm{I}-\mathrm{E}^{\mathrm{u}}$, and p84 binds $\mathrm{I}-\mathrm{A}^{\mathrm{u}}(10)$. A foreign peptide, HEL 106, which contains a sequence similar to p58 with an alternating basic charge amino acid motif and binds avidly to $\mathrm{I}-\mathrm{E}^{\mathrm{d}}$ (Table I), did not stimulate T21.8.13. Thus, a single $\mathrm{T}$ cell can be activated by different self-Ig-derived peptides bearing different sequences and different MHC binding motifs.

Hybridomas activated in the presence of self-APCs without any added antigen. Three hybridomas were stimulated by selfAPCs independent of added peptides (hybridoma T34.7 in Fig. 2, right). T34.7 also recognizes APCs from MHC class II (H$\left.2^{\mathrm{du}}\right)$-matched $(\mathrm{BALB} / \mathrm{c} \times \mathrm{NZW}) \mathrm{F}_{1}$ and $\mathrm{BALB} / \mathrm{c}$ mice (data not shown). These $\mathrm{T}$ cells apparently recognize self-ligands displayed on APCs from autoimmune as well as normal strains.

\section{Protein database search for proteins containing identical sequences}

Molecular mimicry and cross-recognition with a foreign or self-antigen may lead to the activation and expansion of autoreactive T cells $(14,18-21)$. To determine if sequence-based molecular mimicry with other antigens was likely to be responsible for Ig peptide-mediated T cell help in our system, we analyzed an all nonredundant protein database for sequences

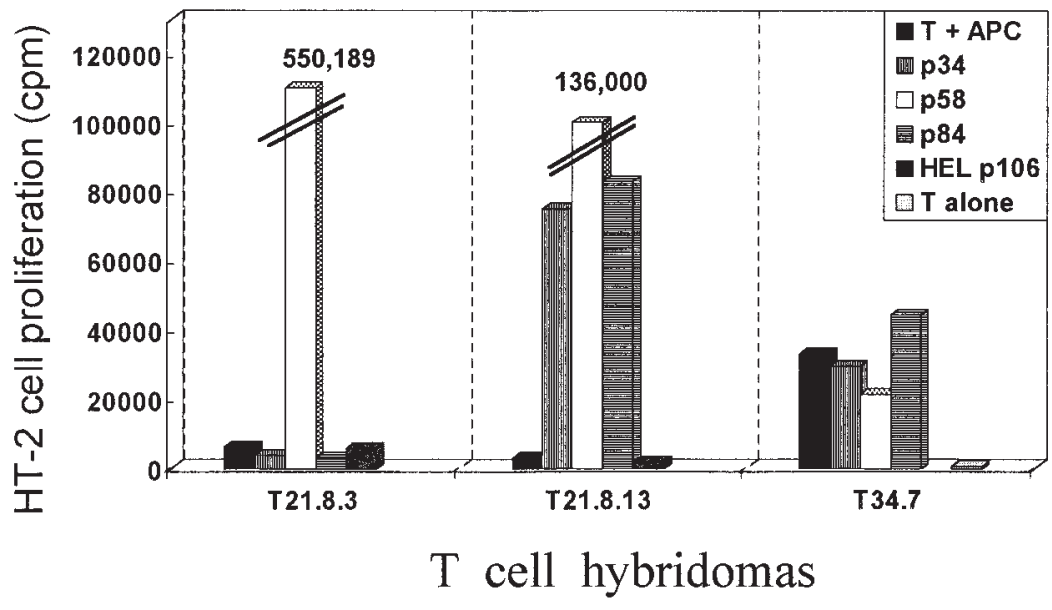

Figure 2. Degenerate recognition by an Ig peptidereactive $\mathrm{T}$ cell. Nine $\mathrm{T}$ cell hybridomas were generated from $\mathrm{BWF}_{1}$ mice immunized with p58. Stimulation of hybridomas was assayed as proliferation of HT-2 cells incubated with supernatants of cultures containing T cell hybridomas and syngeneic APCs without or with Ig peptides or a foreign peptide (HEL p106). Proliferation of HT-2 cells was measured by $\left[{ }^{3} \mathrm{H}\right]$ thymidine uptake assay. Results of three representative hybridomas are shown as cpm. Four hybridomas represented in the figure by T21.8.3 were exquisitely p58-specific (left); two represented by T21.8.13 responded to all three self-determinants tested but not to HEL p106 (middle). The remaining three hybridomas including T34.7 were stimulated by self-APCs independent of added peptides (right). The data shown are representative of at least two experiments for each hybridoma. 
Table III. Ig-derived T Cell Stimulatory Peptides Are Infrequent in Ig V Regions and Absent in Other Proteins

\begin{tabular}{lcl}
\hline \multicolumn{1}{c}{ Peptides* } & $\begin{array}{c}\text { Identical sequences } \\
\text { in database }\end{array}$ & \multicolumn{1}{c}{$\begin{array}{c}\text { Amino acid changes } \\
\text { from germline }\end{array}$} \\
\hline p34 & $52(0.015 \%)$ & $\mathrm{M}_{5} \rightarrow \mathrm{K}$ \\
p58 & $17(0.005 \%)$ & None \\
p84 & $1(0.0003 \%)$ & $\mathrm{V}_{6} \rightarrow \mathrm{L}$ \\
p33 (Bwds3) & $1(0.0003 \%)$ & $\mathrm{S} / \mathrm{N}_{3} \rightarrow \mathrm{T}, \mathrm{P}_{9} \rightarrow \mathrm{T}$
\end{tabular}

*Peptides p34, p58, and p84 are 12-mers, and p33 is a 15-mer. ₹Determinants were analyzed by BLAST searches for identical matches and for changes from germline in all nonredundant GenBank database ( $n=347,235$ on June 16, 1998). All identical sequences were contained in the $\mathrm{V}_{\mathrm{H}}$ regions of mouse Ig.

identical to selected Ig-derived stimulatory peptides. Determinant A6.1 p84 and Bwds3 p33 each occurred only in 0.0003\% of sequences in the database, A6.1 p58 in $0.005 \%$, and A6.1 p34 in $0.015 \%$ of the searched sequences. Furthermore, Igderived $\mathrm{T}$ cell determinant sequences occurred rarely in Ig $\mathrm{V}_{\mathrm{H}}$ regions, but never in other proteins (Table III).

We also analyzed amino acid replacements from the best matched germline-encoded sequences; p34 and p84 each had one change, and Bwds3 p33 had two changes. Only p58 had no change from the germline (Table III).

\section{Analysis of matched sequences reveals that Ig determinants frequently occur in auto $A b$ but not in normal $A b$}

The findings in Table III suggest that despite the location of portions of these peptides in frameworks of $\mathrm{Ab} \mathrm{V}_{\mathrm{H}}$ regions and absence of change from germline sequences in some, their sequences are rarely used. This is particularly true of A6.1 p84 and Bwds3 p33. Analysis of antigen specificity of Ab containing these sequences shows that for A6.1 p34, 69\% of matched sequences in the database are derived from autoAb, the majority of which are anti-DNA (Table IV). For A6.1 p58 germ- line sequence, utilization is infrequent and is predominantly $(59 \%)$ found in auto Ab. The other autoAb in which the p34 and p58 sequences occur are those which are frequently present in humans and mice with SLE, such as anticardiolipin and antierythrocyte $\mathrm{Ab}$, and rheumatoid factor. Overall, it is striking that almost half of the mouse Ig using these peptide sequences are anti-DNA.

The increased utilization of Ig determinant sequences among auto $\mathrm{Ab}$ (to DNA and other self-antigens) was highly significant compared with the overall representation of these Abs in the GenBank database (Table IV).

Peptides shown in Table III are derived from two antiDNA mAbs, A6.1 and BWds3, both of which use the $\mathrm{V}_{\mathrm{H}}$ gene family J558 (16). The J558 gene family is commonly used by anti-DNA $\mathrm{Ab}$ in lupus-prone $\mathrm{BWF}_{1}$ and MRL-lpr/lpr mice $(6$, 16, 22-26). To determine if these peptide sequences occur commonly in anti-DNA $\mathrm{Ab}$, we screened their $\mathrm{V}_{\mathrm{H}}$ region sequences in the literature. The analysis suggests that the sequences of Ig-derived $\mathrm{T}$ cell determinants are quite common in anti-DNA Ab from two genetically unrelated mouse strains with SLE (Fig. 3).

To test the importance of amino acid residues common to these mAb anti-DNA, we synthesized analogues of p58 in which one of each of the residues was substituted with alanine (A). A p58-specific hybridoma, T21.8.3, was used as an indicator cell. Supernatants of T21.8.3 cultured with each of the peptide analogues and APCs were tested for IL-2 as measured by HT-2 cell proliferation (Fig. 4). In the wild 12-mer FYNQKFKGKATL, $\mathrm{F}$ at position one $\left(\mathrm{F}_{1}\right), \mathrm{Q}_{4}$, or $\mathrm{L}_{12}$ could be replaced with $\mathrm{A}$ without any loss of the $\mathrm{T}$ cell activating property. Substitution of any of the other residues with A resulted in a significant decrease of $\mathrm{T}$ cell activation.

In Fig. 3, note that p58, $\mathrm{Y}_{2}, \mathrm{~N}_{3}, \mathrm{~F}_{6}, \mathrm{~K}_{7}, \mathrm{~K}_{9}$, and $\mathrm{T}_{11}$-which cannot be substituted without losing $\mathrm{T}$ cell proliferation in a p58-specific $\mathrm{T}$ cell hybridoma (shown in Fig. 4) - are all retained in multiple murine $\mathrm{mAb}$ anti-DNA from two different strains of lupus mice. These data suggest selection bias for anti-DNA to utilize certain peptide sequences in $V_{H}$ that are $T$

Table IV. Most Matched Sequences in the Database Are Derived from AutoAb But Not from the Normal Immune Repertoire

\begin{tabular}{|c|c|c|c|c|}
\hline \multirow[b]{2}{*}{ Peptides } & \multicolumn{4}{|c|}{ Specificity of the matched sequences } \\
\hline & Anti-DNA & $\begin{array}{l}\text { Against other } \\
\text { self-antigen** }\end{array}$ & $\begin{array}{c}\text { Against other } \\
\text { non-self-antigen }\end{array}$ & Unknown $^{\S}$ \\
\hline p34 & 23 & 14 & 8 & 7 \\
\hline p58 & 8 & 2 & 4 & 3 \\
\hline $\mathrm{p} 84$ & 1 & 0 & 0 & 0 \\
\hline p33 (Bwds3) & 1 & 0 & 0 & 0 \\
\hline Total & $33(46.5 \%)$ & $16(22.5 \%)$ & $12(17 \%)$ & $10(14 \%)$ \\
\hline Representation of $\mathrm{Ab}$ sequences in the database $\mathrm{l}^{\|}$ & $8(7.1 \%)$ & $8(7.1 \%)$ & $79(69.9 \%)$ & $18(15.9 \%)$ \\
\hline$P$ & $<0.001^{q}$ & $<0.01^{\text {qा }}$ & $<0.001 * *$ & NS \\
\hline
\end{tabular}

* Other autoAb include anticardiolipin, anti-red blood cell, anti-type 2 collagen, rheumatoid factor, and Ab encoded by overexpressed mRNA with unknown specificity from autoimmune mice. ${ }^{\ddagger}$ Include $\mathrm{Ab}$ raised against immunizing protein antigens, haptens, idiotypes, and dextran. ${ }^{\S}$ Uncharacterized and germline sequences. "All 443 mouse Ig heavy chain sequences were retrieved from the GenBank database (www. ncbi.nlm.nih.gov/Entrez/nucleotide.html). To determine the representation of Ab sequences in the database, we looked up specificities of the first five items per every 20 entries in a page. There were 23 pages. The last page had only three entries. Thus, 113 entries were screened for their antigenic specificities. $\chi^{2}$ analysis revealed that sequences for Ig determinants occurred more frequently in anti-DNA and other autoAbs compared with the representation of these $\mathrm{Ab}$ sequences in the database $(\mathbb{I} P<0.001$ to $<0.01)$. Ab to foreign antigens, on the other hand, were represented less often in the matching sequences of Ig determinants than in the database $(* * P<0.001) . N S$, not significant. 


\begin{tabular}{|c|c|c|c|c|c|c|}
\hline Anti-DNA & $\begin{array}{l}\text { Strain of } \\
\text { origin }\end{array}$ & p34 & p58 & $p 84$ & $\begin{array}{c}V_{H} \text { gene } \\
\text { family }\end{array}$ & Ref. \\
\hline A6.1 & BWF1 & MNWUKQSHGKSL & FYNQRFKGKATL & SEDSALYYCARD & $\sqrt{ } 558 \mathrm{i}^{*}$ & 16 \\
\hline 5 GD5 & BWF1 & - & s......... & $----V--V G$ & J558 $\mathrm{j}$ & 16 \\
\hline BWds3 & BWF1 & IT-- - -RT-QG- & $\mathbf{Y}--\mathbf{E}-\cdots-\cdots$ & $----V-F---E$ & $J 558 \mathrm{j}$ & 16 \\
\hline 165.14 & BWF1 & - & n- & $\cdots-V-\cdots-R$ & J558; & 23 \\
\hline 165.60 & BWF1 & --- & -- & $----V----G$ & $\mathrm{~J} 558 \mathrm{j}$ & 23 \\
\hline $17 \mathrm{~s}-\mathrm{cl}$ & BWF1 & --- & 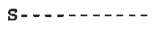 & $-----V-----E$ & $\mathrm{~J} 558 \mathrm{i}$ & 23 \\
\hline 163.72 & BWF1 & -DW- & s- $\ldots \ldots \ldots$ & $----V-\cdots-R$ & J558 j & 23 \\
\hline $25.12 \mathrm{~m}$ & BWF1 & D & G-N-DS- & $----V-\cdots-G$ & $\sqrt{ } 558 \mathrm{j}$ & 23 \\
\hline $17 \mathrm{~s} .166$ & BWF1 & -F[-- - - PE- - & T-N-DA & - - V - - - G & $\sqrt{558} \mathrm{i}$ & 23 \\
\hline $17 s .128$ & BWF1 & $-\ldots$ & $s+\cdots$ & $----\mathrm{V}-\cdots-\mathrm{A}$ & $\mathrm{J} 558 \mathrm{i}$ & 23 \\
\hline BXW16 & BWF1 &.- & s-. & $-\cdots-\mathrm{V}-\cdots$ & J558 j & 25 \\
\hline $\mathrm{H} 102$ & MRL/ipr & -- & s......... & $-\ldots-\mathrm{V}-\ldots-\ldots$ & $\sqrt{558 i}$ & 26 \\
\hline $\mathrm{H} 241$ & MRL/or & -- & s-..... & $\ldots-V_{n}-\ldots$ & $\mathrm{J} 558 \mathrm{i}$ & 26 \\
\hline $82-3$ & MRL/pr & $\ldots$ & s-lns & $-----V-D$ & $\mathrm{~J} 558 \mathrm{j}$ & 57 \\
\hline BV16-19 & BWF1 & - & $S---Q-\cdots---$ & $----V-\cdots---$ & J558 j & 58 \\
\hline A52 & BWF1 & $\ldots$ & s-- $-1-0--$ & 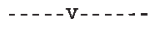 & $\mathrm{J} 558 \mathrm{j}$ & 59 \\
\hline $\mathrm{C} 72$ & BWF1 & $\ldots-\ldots$ & s- & - - - -TV - - - - & $\mathrm{J} 558 \mathrm{j}$ & 60 \\
\hline $45-5$ & MRLipr & - - - - & S- - - - - & $-----V-\cdots--$ & J558 j & 61 \\
\hline
\end{tabular}

Figure 3. T cell determinants derived from A6.1 are very commonly used in the murine anti-DNA Ab derived from $\mathrm{BWF}_{1}$ or MRL-lpr/lpr mice. The sequences are from the literature $(16,22-26,57-61)$.

Dashes indicate identity with the A6.1 $\mathrm{V}_{\mathrm{H}}$ sequence. *Haplotype.

cell determinants, thus providing an upregulating stimulus that sustains autoAb production.

\section{Discussion}

In this paper we asked How does autoreactivity involve several antigenic targets in individuals with autoimmune diseases? To address this question we used a system where certain peptides derived from self-reactive $\mathrm{Ab}$ influence autoAb production and disease via activation of autoreactive $\mathrm{T}$ cells in a spontaneous autoAb-mediated disease model, $\mathrm{BWF}_{1}$ mice (7-10). We considered three possibilities which might explain multiclonality in an autoimmune response. First, the autoreactive $\mathrm{T}$ cell responses initiate with a few determinants and subsequently diversify to involve several determinants across the native molecule, through determinant spreading (27-29). Second, $\mathrm{T}$ cells raised against one determinant might recognize several additional determinants in a degenerate manner, possibly through sharing of relevant $\mathrm{T}$ cell receptor (TCR) contact residues. Third, the autoantigenic $\mathrm{T}$ cell determinants (self-Ig peptides in this case) might exhibit molecular mimicry with other autoantigens through sharing of MHC-binding or TCR contact sequences. We also raise a novel possibility that self-Ig peptides that augment autoimmunity might occur commonly in auto $\mathrm{Ab}$, so that $\mathrm{T}$ cells reactive with one determinant can stimulate B cells of several specificities.

In an immune response to an antigen, the initial recognition is directed to a few easily processed and displayed ("dominant") determinants. With time, this reactivity spreads to other parts of the molecule ("intramolecular spreading") and
Proliferation of HT-2 cells (cpm)

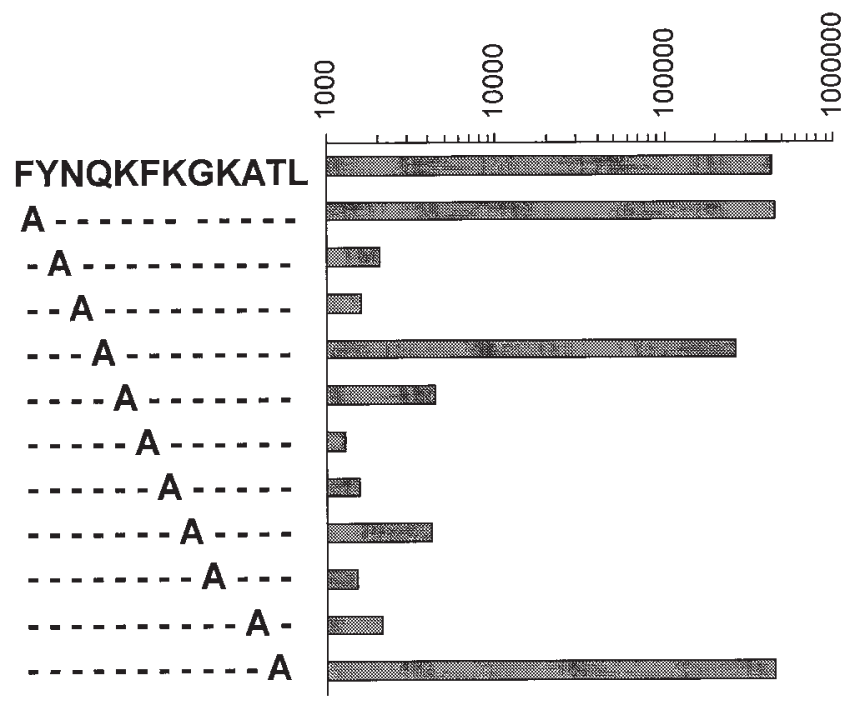

Figure 4. Influence of alanine (A) substitutions on T cell activation by $\mathrm{p} 58$. Each residue in the p58 was substituted with A, using a modified pin synthesis method (8). These peptide analogues were cultured separately with p58-reactive hybridoma (T21.8.3) cells and APCs (syngeneic irradiated spleen cells). After $24 \mathrm{~h}$, supernatants were removed and tested for the presence of IL-2 by incubating with the indicator cells, HT-2. Data are presented as mean cpm of triplicate cultures in a representative one of two experiments. Background and Con-A-positive control cpm values were 712 and 47,553, respectively (not shown in figure). Dashes indicate identity with the p58 sequence. Note that residues at position one $\left(\mathrm{F}_{1}\right), \mathrm{Q}_{4}$, and $\mathrm{L}_{12}$ could be substituted without losing the $\mathrm{T}$ cell determinant.

similarly to other molecules in the local vicinity ("intermolecular spreading") (30). In a prototype case of determinant spreading in experimental autoimmune encephalomyelitis, autoreactivity induced by a single self-peptide (Ac1-11) gave rise to reactivity to other subdominant or cryptic determinants elsewhere on the immunogen as well as on other self-immunogens at the inflammatory site (31). This process develops as a predictable sequential cascade of neo-autoimmunity resulting from endogenous self-priming during progression to chronic disease (32). Neo-autoreactive T cells generated during determinant spreading can transfer acute experimental autoimmune encephalomyelitis in naive recipients $(32,33)$, even when $\mathrm{T}$ cells reactive to the initial priming antigen are eliminated (34).

Mamula and associates proposed a critical role of B cells in T-B cell diversification $(35,36)$. According to their model (35), professional APCs initiate immune response by presentation of dominant peptides to CD4 T cells, which then activate antigen-specific B cells. The antigen-specific B cell, through its great capacity of increased antigen uptake, allows for heightened presentation of certain subdominant or cryptic peptides (that otherwise would be less available for binding to MHC class II molecules) at levels sufficient to stimulate a CD4 T cell. In this way, antigen-specific B cells can drive the recruitment of a diverse population of CD4 T cells.

In this paper we describe another type of T-B cell diversification, reciprocal T-B determinant spreading (37). According 
to our model, the Ig itself is processed and presented to the original antigen-specific $\mathrm{T}$ cells, which will reciprocally activate B cells. Additionally, the antigen-specific Ig receptors may capture autoantigens, which are likely to be processed into different peptides and, thus, activate a diverse array of $\mathrm{T}$ cells. The resultant spreading of the B cell response intramolecularly and intermolecularly can allow autoreactivity to expand, and it is likely to play an important role in SLE.

The enhanced T-B cell diversification in autoimmune conditions may occur through several different mechanisms, including a potent antigen processing or presentation, structural organization of the autoantigen (38-40; see below), promiscuous binding to different MHC molecules (41), display of related determinants by activated B cells $(35,36)$, enhanced cytokine production, and an unusually effective cross-stimulation of $\mathrm{T}$ and B cells. SLE B cells are hyperactivated and secrete increased quantities of cytokines $(3,4)$. The activated B cells may enhance the processing and presentation of autoantigens in lupus-prone individuals. An upregulation of costimulatory molecules may also contribute to the activation of newly recruited $\mathrm{T}$ cells responsible for epitope spreading (42). Additionally, autoimmune $\mathrm{T}$ cells may have an inherent defect causing them to respond spontaneously and to diversify vigorously.

To explain the occurrence of linked sets of autoAb in human and murine SLE, Craft and Fatenejad emphasized the role of intact macromolecular particles in T-B cell diversification (38-40). They and others showed that once immune tolerance to one component of a macromolecular particle, such as small nuclear ribonucleoprotein ( $\mathrm{snRN}$ ), is abrogated, the auto $\mathrm{Ab}$ response diversifies to other components via recognition of new epitopes within the intact complex $(38-40,43,44)$. However, this model does not explain the findings of James et al., where rabbits immunized with a single snRNP peptide developed $\mathrm{Ab}$ not only to different epitopes of snRNP particle but also to DNA (45).

At the $\mathrm{T}$ cell recognition level, there is the cross-reactive recognition of very similar determinants and also the degenerate recognition characteristic of TCR which would further broaden the repertoire. To determine if molecular mimicry and cross-recognition with other antigens were likely to be responsible for Ig peptide-mediated T cell help in our system, a protein database search for several Ig-derived $\mathrm{T}$ cell determinants was done. Identical sequences occurred rarely in $\mathrm{Ig}$ heavy chains and never in non-Ig proteins (Table III). However, this does not rule out sequence identity with unreported protein sequences, or cross-stimulation with antigenic peptides that are less homologous. Indeed, Bhardwaj et al. (46) and later Wucherpfennig and Strominger (18) showed that autoreactive $T$ cells could recognize apparently dissimilar peptides, which did not share sequence homologies with the autoantigen in positions other than TCR contact residues $(18,19)$. Our data that a single $\mathrm{T}$ cell hybridoma established from a $\mathrm{BWF}_{1}$ mouse immunized with one self-peptide recognized several self-Ig peptides (Fig. 2) are interesting since these three peptides have different sequences, and one of them (p84) does not even bind the MHC class II molecules that restrict the original immunizing peptide, p58 (10). Altogether, evidence suggests that when tested critically $\mathrm{T}$ cell antigen recognition is highly degenerate $(20,47)$. This poorly restricted specificity of the TCR can very well be explained from the recently solved three-dimensional structure of TCR-MHC-peptide complexes
$(48,49)$. As most of the peptide is buried in the peptide-binding pocket of the $\mathrm{MHC}$ molecule, only a few amino acid residues protruding upward from the groove make direct contact with the TCR.

In our previous work (7), it was highly surprising that treatment that resulted in tolerization to three peptides from a single $\mathrm{V}_{\mathrm{H}}$ region should have an overall effect on disease, since Abs to DNA and other autoantigens would certainly be using diverse $\mathrm{V}_{\mathrm{H}}$ regions. However, for anti-DNA $\mathrm{Ab}$ there is limited $\mathrm{B}$ cell clonality $(23,50)$ with dominance of the $\mathrm{BWF}_{1}$ auto $\mathrm{Ab}$ repertoire by $\mathrm{V}_{\mathrm{H}} \mathrm{J} 558$-encoded $\mathrm{Ig}(6,16,22-26)$. In a recent study, one $\mathrm{V}_{\mathrm{H}}$ gene $\left(\mathrm{V}_{\mathrm{H}} \mathrm{BW}-16\right)$ of the large $\mathrm{J} 558$ family was very rarely used in Igs of normal mice, but was dramatically increased in Igs from $\mathrm{BWF}_{1}$ mice (22). Consistent with these observations, we found that sequences similar to A6.1 p34, p58, and p84 were commonly found in anti-DNA Ab from lupus mice (Fig. 3 and Table IV). Additionally, however, the T cell stimulatory peptide sequences also occurred in other auto $\mathrm{Ab}$, including Abs to cardiolipin, erythrocytes, type 2 collagen, and IgG Fc (Table IV). These observations lead us to speculate that $\mathrm{T}$ cells raised against peptides derived from one auto $\mathrm{Ab} \mathrm{V}$ region may not only stimulate $\mathrm{B}$ cells capable of making the same Ab but also B cells capable of making several different $\mathrm{Ab}$ bearing a similar $\mathrm{V}$ region sequence. For example, $\mathrm{T}$ cells reactive with $\mathrm{V}$ region peptides from anticardiolipin may stimulate B cells specific for Ab to erythrocytes bearing the same $\mathrm{V}$ region sequence. According to this scheme, molecular mimicry between cardiolipin and erythrocyte antigens would not be required for generation of cross-reactive Ab. In fact, mAbs that bind both cardiolipin and DNA, or cardiolipin and $\mathrm{IgG} \mathrm{Fc}$, have been described (51-54). Thus, a high degree of commonality of these peptide sequences in lupus auto $\mathrm{Ab}$ could explain the general effect of one or a few peptides on a broader auto $\mathrm{Ab}$ repertoire.

In conclusion, we describe in our model of Ig-derived peptides multiple mechanisms of autoimmunity propagation. Reciprocal activation of T-B cells by these auto Ab leads to a continuous recruitment of neo-autoreactive Th cells, ultimately resulting in pathogenic autoimmunity in a genetically predisposed strain. Such spontaneous expansion must be important in disease, since tolerance induction to a set of these Ig peptides before disease onset delays autoAb production and nephritis (7). Ig peptides are not the only source of $\mathrm{T}$ helper determinants for anti-DNA Ab production. Nucleosomeautoreactive $\mathrm{T}$ cells also augment anti-DNA production in murine and human SLE $(55,56)$. Rabbits immunized with the $\mathrm{B} / \mathrm{B}^{\prime}$ peptide of the snRNP particle developed $\mathrm{Ab}$ to DNA, with Ig deposition in glomeruli (45). It is likely that determinants from several different antigens can activate autoreactive $\mathrm{T}$ cell help for pathogenic anti-DNA production in SLE, perhaps through an interconnected circuitry of reciprocal T-B cell recognition. In this way activation of $\mathrm{T}$ cells reactive with one or a few self-Ig peptides would result in stimulation of a diverse array of $\mathrm{B}$ cells causing polyclonal auto $\mathrm{Ab}$ response in SLE. It is not clear from our study how much of this polyclonal activation is a result of true determinant spreading and how much of it is due to generation of T cells that react to many degenerate peptide sequences. An understanding of these processes would have important implications in designing antigenbased therapies for autoimmune diseases that can target a broad array of related autoreactive $\mathrm{T}$ and $\mathrm{B}$ cell responses while sparing unrelated normal immune defenses. 


\section{Acknowledgments}

We sincerely thank Kristi Chang and Jonathan Jacinto for technical help, Carlos Nava for animal care, and Eli Sercarz, Kamal Moudgil, and Rhonda Vohskul for helpful suggestions.

This work was supported in part by grants from the National Institutes of Health, Arthritis Foundation grants, and the Paxson funds. R.R. Singh is a recipient of an Arthritis Investigator Award from the National Arthritis Foundation.

\section{References}

1. Dziarski, R. 1988. Autoimmunity: polyclonal activation or antigen induction? Immunol. Today. 9:340-342.

2. Rozzo, S.L., C.G. Drake, B.-L. Chiang, M.E. Gershwin, and B.L. Kotzin. 1994. Evidence for polyclonal T cell activation in murine models of systemic lupus erythematosus. J. Immunol. 153:1340-1351.

3. Klinman, D. 1990. Polyclonal B cell activation in lupus-prone mice precedes and predicts the development of autoimmune disease. J. Clin. Invest. 86: 1249-1254.

4. Merino, R., M. Iwamoto, L. Fossati, and S. Izui. 1993. Polyclonal B cell activation arises from different mechanisms in lupus-prone (NZBxNZW) $\mathrm{F}_{1}$ and MRL/MpJ-lpr/lpr mice. J. Immunol. 151:6509-6516.

5. Klinman, D.M., A. Shirai, and Y. Ishigatsubo. 1994. Polyclonal B cell activation and B cell cross-reactivity during autoantibody production in SLE. Adv. Exp. Med. Biol. 347:115-123.

6. Radic, M.Z., and M. Weigert. 1994. Genetic and structural evidence for antigen selection of anti-DNA antibodies. Annu. Rev. Immunol. 12:487-520.

7. Singh, R.R., F.M. Ebling, E.E. Sercarz, and B.H. Hahn. 1995. Immune tolerance to autoantibody-derived peptides delays development of murine lupus. J. Clin. Invest. 96:2990-2996.

8. Ebling, F.M., B.P. Tsao, R.R. Singh, E. Sercarz, and B.H. Hahn. 1993. A peptide derived from an autoantibody can stimulate $\mathrm{T}$ cells in the $(\mathrm{NZB} \times$ NZW) $\mathrm{F}_{1}$ mouse model of systemic lupus erythematosus. Arthritis Rheum. 36: $355-363$.

9. Singh, R.R., B.H. Hahn, and F.M. Ebling. 1996. Autoantibody-derived peptides can induce autoantibodies in normal mice. Arthritis Rheum. 39:S108. (Abstr.)

10. Singh, R.R., V. Kumar, F.M. Ebling, S. Southwood, A. Sette, E.E. Sercarz, and B.H. Hahn. 1995. T cell determinants from autoantibodies to DNA can upregulate autoimmunity in murine lupus. J. Exp. Med. 181:2017-2027.

11. Waisman, A., P.J. Ruiz, E. Israeli, E. Eilat, S. Konen-Waisman, H. Zinger, M. Dayan, and E. Mozes. 1997. Modulation of murine systemic lupus erythematosus with peptides based on complementarity determining regions of a pathogenic anti-DNA monoclonal antibody. Proc. Natl. Acad. Sci. USA. 94: $4620-4625$.

12. Williams, W.M., N.A. Staines, S. Muller, and D.A. Isenberg. 1995. Human $\mathrm{T}$ cell responses to autoantibody variable region peptides. Lupus. 4:464471.

13. Linker-Israeli, M., F.M. Ebling, D.J. Wallace, R.R. Singh, R. Nand, P. Lin, J.R. Klinenberg, and B.H. Hahn. 1996. T cells of SLE patients recognize VH determinants of anti-dsDNA autoantibodies. Arthritis Rheum. 39:S267. (Abstr.)

14. Avery, A.C., Z.-S. Zhao, A. Rodriguez, E.K. Bikoff, M. Sohellian, C.S. Foster, and H. Cantor. 1995. Resistance to herpes stromal keratitis conferred by an IgG2a-derived peptide. Nature. 376:431-434.

15. Van Schooten, W.C., D. Devereux, C.H. Ho, J. Quan, B.A. Aguilar, and C.J. Rust. 1994. Joint-derived T cells in rheumatoid arthritis react with selfimmunoglobulin heavy chains or immunoglobulin-binding proteins that copurify with immunoglobulin. Eur. J. Immunol. 24:93-98.

16. Ohnishi, K., F.M. Ebling, B. Mitchell, R.R. Singh, B.H. Hahn, and B.P. Tsao. 1994. Comparison of pathogenic and nonpathogenic murine antibodies to DNA: antigen binding and structural characteristics. Int. Immunol. 6:817-830.

17. Hartman, A.B., C.P. Mallett, S. Sheriff, and S.J. Smith-Gill. 1988. Unusual joining sites in the $\mathrm{H}$ and $\mathrm{L}$ chains of an anti-lysozyme antibody. J. Immunol. 141:932-936.

17a. Ando, D.G., F.M. Ebling, and B.H. Hahn. 1986. Detection of native and denatured DNA antibody forming cells by the enzyme-linked immunospot assay. Arthritis Rheum. 29:1139-1146.

17b. Ando, D.G., E.E. Sercarz, and B.H. Hahn. 1987. Mechanisms of T and $\mathrm{B}$ cell collaboration in the in vitro production of anti-DNA antibodies in the NZB/NZW F $F_{1}$ murine SLE model. J. Immunol. 138:3185-3190.

18. Wucherpfennig, K.W., and J.L. Strominger. 1995. Molecular mimicry in $\mathrm{T}$ cell-mediated autoimmunity: viral peptides activate human $\mathrm{T}$ cell clones specific for myelin basic protein. Cell. 80:695-705.

19. Hemmer, B., B.T. Fleckenstein, M. Vergelli, G. Jung, H. McFarland, R. Martin, and K.-H. Wiesmuller. 1997. Identification of high potency microbial and self-ligands for a human autoreactive class II restricted T cell clone. J. Exp. Med. 185:1651-1659.
20. Barnaba, V., and F. Sinigaglia. 1997. Molecular mimicry and T cellmediated autoimmune disease. J. Exp. Med. 185:1529-1531.

21. Lou, A.-M., K.M. Garza, D. Hunt, and K.S.K. Tung. 1993. Antigen mimicry in autoimmune disease: sharing of amino acid residues critical for pathogenic T cell activation. J. Clin. Invest. 92:2117-2123.

22. Ash-Lerner, A., M. Ginsberg-Strauss, Y. Pewzner-Jung, D.D. Desai, T.N. Marion, and D. Eilat. 1997. Expression of an anti-DNA-associated VH gene in immunized and autoimmune mice. J. Immunol. 159:1508-1519.

23. Tillman, D.M., N.-T. Jou, R.J. Hill, and T.N. Marion. 1992. Both IgM and IgG anti-DNA antibodies are the products of clonally selective B cell stimulation in $(\mathrm{NZB} \times \mathrm{NZW}) \mathrm{F}_{1}$ mice. J. Exp. Med. 176:761-779.

24. Tsao, B.P., F. Ebling, C. Roman, N. Panosian-Sahakian, K. Calame, and B.H. Hahn. 1990. Structural characteristics of the variable regions of an immunoglobulin gene coding a pathogenic autoantibody in murine lupus. J. Clin. Invest. 85:530-540.

25. Kofler, R., R. Strohal, R.S. Balderas, M.E. Johnson, D.J. Noonan, M.A. Duchosal, F.J. Dixon, and A.N. Theofilopoulos. 1988. Immunoglobulin $\kappa$ light chain variable region gene complex organization and immunoglobulin genes encoding anti-DNA autoantibodies in lupus mice. J. Clin. Invest. 82:852-860.

26. Gangemi, R.M.R., A.K. Singh, and K.J. Barrett. 1993. Independently derived IgG anti-DNA autoantibodies from two lupus-prone mouse strains express a VH gene that is not present in most murine strains. J. Immunol. 151: 4660-4671.

27. Perry, L.L., and M.E. Barzaga. 1987. Kinetics and spreading of T and B cell responses in relapsing experimental allergic encephalomyelitis. J. Immunol. 138:1434-1441.

28. Lehmann, P.V., E.E. Sercarz, T. Forsthuber, C.M. Dayan, and G. Gammon. 1993. Determinant spreading and the dynamics of the autoimmune T-cell repertoire. Immunol. Today. 14:203-208.

29. Vanderlugt, C.J., and S.D. Miller. 1996. Epitope spreading. Curr. Opin. Immunol. 8:831-836.

30. Kaufman, D.L., M. Clare-Salzler, J. Tian, T. Forsthuber, G.S.P. Ting, P. Robinson, M.A. Atkinson, E.E. Sercarz, A.J. Tobin, and P.V. Lehmann. 1993. Spontaneous loss of tolerance to glutamic acid decarboxylase in murine insulindependent diabetes. Nature. 366:69-72.

31. Lehmann, P.V., T. Forsthuber, A. Miller, and E.E. Sercarz. 1992. Spreading of $\mathrm{T}$ cell autoimmunity to cryptic determinants of an autoantigen. Nature. 358:155-157.

32. Yu, M., J.M. Johnson, and V.K. Tuohy. 1996. A predictable sequential determinant spreading cascade invariably accompanies progression of experimental autoimmune encephalomyelitis: a basis for peptide-specific therapy after onset of clinical disease. J. Exp. Med. 183:1777-1788.

33. McRae, B.L., C.L. Vanderlugt, M.C. Dal Canto, and S.D. Miller. 1995. Functional evidence for epitope spreading in the relapsing pathology of experimental autoimmune encephalomyelitis. J. Exp. Med. 182:75-85.

34. Yu, M., J.M. Johnson, and V.K. Tuohy. 1996. Generation of autonomously pathogenic neo-autoreactive Th1 cells during the development of the determinant spreading cascade in murine autoimmune encephalomyelitis. $J$. Neurosci. Res. 45:463-470.

35. Mamula, M.J., and C.A. Janeway, Jr. 1993. Do B cells drive the diversification of immune responses? Immunol. Today. 14:151-152.

36. Mamula, M.J., S. Fatenejad, and J. Craft. 1994. B cells process and present lupus autoantigens that initiate autoimmune $\mathrm{T}$ cell responses. J. Immunol. 152:1453-1461.

37. Singh, R.R., F.M. Ebling, E.E. Sercarz, and B.H. Hahn. 1997. Reciprocal spontaneous $\mathrm{T}$ helper determinant spreading in autoimmune lupus-prone but not in normal strains. J. Invest. Med. 45:112A. (Abstr.)

38. Fatenejad, S., M.J. Mamula, and J. Craft. 1993. Role of intermolecular/ intrastructural B- and T-cell determinants in the diversification of autoantibodies to ribonucleoprotein particles. Proc. Natl. Acad. Sci. USA. 90:12010-12014.

39. Craft, J., and S. Fatenejad. 1997. Self antigens and epitope spreading in systemic autoimmunity. Arthritis Rheum. 40:1374-1382.

40. Fatenejad, S., M. Bennett, J. Moslehi, and J. Craft. 1998. Influence of antigen organization on the development of lupus autoantibodies. Arthritis Rheum. 41:603-612.

41. Shi, Y., A. Kaliyaperumal, L. Lu, S. Southwood, A. Sette, M.A. Michaels, and S.K. Datta. 1998. Promiscuous presentation and recognition of nucleosomal autoepitopes in lupus: role of autoimmune $\mathrm{T}$ cell receptor $\alpha$ chain. J. Exp. Med. 187:367-378.

42. Miller, S.D., C.L. Vanderlugt, D.J. Lenschow, J.G. Poper, N.J. Karandikar, M.C. Dal Canto, and J.A. Bluestone. 1995. Blockade of CD28/B7-1 interaction prevents epitope spreading and clinical relapses of murine EAE. Immunity. 3:739-745.

43. Topfer, F., T. Gordon, and J. McCluskey. 1995. Intra- and inter-molecular spreading of autoimmunity involving the nuclear self-antigens La (SS-B) and Ro (SS-A). Proc. Natl. Acad. Sci. USA. 92:875-879.

44. Reynolds, P., T.P. Gordon, A.W. Purcell, D.C. Jackson, and J. McCluskey. 1996. Hierarchical self-tolerance to T cell determinants within the ubiquitous nuclear self-antigen La (SS-B) permits induction of systemic autoimmunity in normal mice. J. Exp. Med. 184:1857-1870.

45. James, J.A., T. Gross, R.H. Scofield, and J.B. Harley. 1995. Immunoglobulin epitope spreading and autoimmune disease after peptide immunization: 
Sm B/B'-derived $P$ GMRPP and PGIRGP induce spliceosome autoimmunity. $J$. Exp. Med. 181:453-461.

46. Bhardwaj, V., V. Kumar, H.M. Geysen, and E.E. Sercarz. 1993. Degenerate recognition of a dissimilar antigenic peptide by myelin-basic protein-reactive T cells. J. Immunol. 151:5000-5010.

47. Ashwell, J.D., C. Chen, and R.H. Schwartz. 1986. High frequency and nonrandom distribution of alloreactivity in $\mathrm{T}$ cell clones selected for recognition of foreign antigen in association with self class II molecules. J. Immunol. 136:389-395.

48. Garboczi, D.N., P. Ghosh, U. Utz, Q.R. Fan, W.E. Biddison, and D.C. Wiley. 1996. Structure of the complex between human T-cell receptor, viral peptide and HLA-A2. Nature. 384:134-141.

49. Garcia, K.C., M. Degano, R.L. Stanfield, A. Brunmark, M.R. Jackson, P.A. Peterson, L. Teyton, and I.A. Wilson. 1996. An $\alpha / \beta$ T cell receptor structure at 2.5 A and its orientation in the TCR-MHC complex. Science. 274:209219.

50. Shlomchik, M.J., M. Mascelli, H. Shan, M.Z. Radic, D. Pisetsky, A. Marshak-Rothstein, and M. Weigert. 1990. Anti-DNA antibodies from autoimmune mice arise by clonal expansion and somatic mutation. J. Exp. Med. 171: 265-292.

51. Lafer, E.M., J. Rauch, C. Andrzejewski, Jr., D. Mudd, B. Furie, R.S. Schwartz, and B.D. Stollar. 1981. Polyspecific monoclonal lupus autoantibodies reactive with both polynucleotides and phospholipids. J. Exp. Med. 153:897909.

52. Shoenfeld, Y., J. Rauch, H. Masicotte, S.K. Datta, J. Andre-Schwartz, B.D. Stollar, and R.S. Schwartz. 1983. Polyspecificity of monoclonal lupus autoantibodies produced by human-human hybridomas. N. Engl. J. Med. 303:414420 .
53. Rauch, J., H. Tannenbaum, B.D. Stollar, and R.S. Schwartz. 1984. Monoclonal anti-cardiolipin antibodies bind to DNA. Eur. J. Immunol. 14:529-539.

54. Rauch, J., H. Tannenbaum, K. Straaton, H. Masicotte, and J. Wild. 1986. Human-human hybridoma autoantibodies with both anti-DNA and rheumatoid factor activities. J. Clin. Invest. 77:106-112.

55. Kaliyaperumal, A., C. Mohan, W. Wu, and S.K. Datta. 1996. Nucleosomal peptide epitopes for nephritis-inducing helper T cells of murine lupus. $J$. Exp. Med. 183:2459-2470.

56. Desai-Mehta, A., C. Mao, S. Rajagopalan, T. Robinson, and S.K. Datta. 1995. Structure and specificity of $\mathrm{T}$ cell receptors expressed by potentially pathogenic anti-DNA autoantibody-inducing T cells in human lupus. J. Clin. Invest. 95:531-541.

57. Radic, M.Z., M.A. Mascelli, J. Erikson, H. Shan, M. Shlomchik, and M. Weigert. 1989. Structural patterns in anti-DNA antibodies form MRL/lpr mice. Cold Spring Harbor Symp. Ouant. Biol. 54:933-946.

58. Smith, R.G., and E.W. Voss, Jr. 1990. Variable region primary structures of monoclonal anti-DNA autoantibodies from NZB/NZW F $\mathrm{F}_{1}$ mice. Mol. Immunol. 27:463-470.

59. Eilat, D., D.M. Webster, and A.R. Rees. 1988. V region sequences of anti-DNA and anti-RNA autoantibodies from NZB/NZW $F_{1}$ mice. J. Immunol. 141:1745-1753.

60. Eilat, D., and R. Fischel. 1991. Recurrent utilization of genetic elements in $\mathrm{V}$ regions of antinucleic acid antibodies from autoimmune mice. J. Immunol. 147:361-368.

61. Bailey, N.C., V. Fidanza, R. Mayer, G. Massa, M. Fougereau, and C. Bona. 1989. Activation of clones producing self-reactive antibodies by foreign antigen and antiidiotype antibody carrying the internal image of the antigen. $J$. Clin. Invest. 84:744-756. 